\title{
Purification and properties of an extracellular endoglucanase from Myceliophthora thermophila D-14 (ATCC 48104)
}

\author{
Samir K. Roy, Susanta K. Dey, Syamal K. Raha $\dagger$ and S. L. Chakrabarty* \\ Department of Microbiology, Bose Institute, 93/1 Acharya Prafulla Chandra Road, Calcutta 700009, India
}

(Received 17 January 1990; revised 11 May 1990; accepted 7 June 1990)

\begin{abstract}
An extracellular endoglucanase (1,4- $\beta$-glucanohydrolase, EC 3.2.1.4) produced by Myceliophthora thermophila D-14 (ATCC 48104) has been purified to homogeneity by ammonium sulphate precipitation and two consecutive ion-exchange chromatographic steps on DEAE-Sephadex A-50 columns. The enzyme was purified 13-8-fold and was homogeneous by analytical PAGE and SDS-PAGE. It has a high apparent $M_{\mathrm{r}}$, of about 100000 . The $\mathrm{pH}$ and temperature optima for its activity were 4.8 and $65{ }^{\circ} \mathrm{C}$ respectively. The $K_{m}$ of the purified enzyme for CMC (sodium salt) was $3 \mathrm{mg} \mathrm{ml}^{-1}$. The enzyme displayed low activity toward salicin and $p$-nitrophenyl $\beta$-D-glucoside. The activity was enhanced in the presence of $\mathrm{Na}^{+}, \mathrm{K}^{+}$and $\mathrm{Ca}^{2+}$ but effectively inhibited by $\mathrm{Hg}^{2+}, \mathrm{Fe}^{2+}, \mathrm{Mg}^{2+}$, $\mathrm{Cu}^{2+}$ and $\mathrm{NH}_{4}^{+}$. Inhibition studies indicated that the enzyme may be a metalloprotein and/or that it requires metal ions for its optimum activity.
\end{abstract}

\section{Introduction}

There have been a number of reports on the microbial hydrolysis of cellulose and, especially in the last decade, many papers have appeared on cellulolysis and cellulases. Cellulase is the key enzyme of potential use for the bioconversion of cellulosic materials to simple sugars, which can serve as feedstock for production of different chemicals and fuels. Cellulases from various cellulolytic microorganisms have been studied, but considerable attention has been paid only to those from efficient producers, such as Trichoderma reesei (Mandels, 1982), Clostridium thermocellum (Ng \& Zeikus, 1981), Thermomonospora sp. (Moreira et al., 1981), Cellulomonas sp. (Langsford et al., 1984), Bacillus subtilis (Au \& Chan, 1987). The cellulases from thermophiles, with the ability to operate at temperatures at or above $55^{\circ} \mathrm{C}$, provide some advantages, including an increased reaction rate and a stable enzyme system (Rosenberg, 1975). Moreover, the elevated growth temperature of the thermophiles, and the high operating temperature and lower $\mathrm{pH}$ requirement of the cellulases from these microbes, restrict the growth of contaminating organisms (Romanelli et al., 1975; Eriksen \& Goksoyr, 1974).

† Present adddress: Efamol Research Institute, Annapolis Valley, Industrial Park, PO Box 818, Kentville, Nova Scotia, Canada, B4N 4H8.

Abbreviations: PCMB, p-chloromercuribenzoate; PNPG, p-nitrophenyl $\beta$-D-glucoside.
Myceliophthora thermophila D-14, a thermophilic fungus possessing a unique cellulase system, was isolated in this laboratory and its cellulolytic activity reported (Sen et al., 1981, 1982, 1983). It produces all three basic cellulase components in extracellular culture filtrates in appreciable amount (Sen et al., 1982; Roy et al., 1990). Because cellulase activity is associated with an enzyme complex, it was considered necessary to examine the properties of the purified cellulase components of this organism. The thermostable property of the enzyme (up to $65-70^{\circ} \mathrm{C}$ ) and occurrence of a relatively greater amount of the $\beta$-glucosidase component also deserved special attention. This paper describes the purification and partial characterization of a major endoglucanase (EC 3.2.1.4) of M. thermophila, which has not previously been reported.

\section{Methods}

Chemicals. Carboxymethylcellulose (CMC; sodium salt), p-nitrophenyl $\beta$-D-glucoside (PNPG), salicin, BSA, Coomassie brilliant blue $\mathrm{R}, \boldsymbol{M}_{\mathrm{r}}$ marker proteins, $\alpha$-cellulose and ammonium persulphate were obtained from Sigma. Sephadex G-200 (superfine), DEAE-Sephadex A-50 and blue dextran were purchased from Pharmacia. 3,5Dinitrosalicylic acid and ammonium sulphate were products of $E$. Merck. D-Glucose and acrylamide were obtained from BDH. Bisacrylamide and $N, N, N^{\prime}, N^{\prime}$-tetramethylethylenediamine were purchased from Koch-Light and SRL (India), respectively. All other chemicals were obtained from commercial sources and were of analytical grade. 
Organism and culture conditions. The thermophilic fungus Myceliophthora thermophila D-14, isolated from city waste (Sen et al., 1981) was used. It was maintained on Czapek-Dox agar slants with $1 \%(w / v)$ glucose and $1 \%(\mathrm{w} / \mathrm{v}) \mathrm{CMC}$ at $45^{\circ} \mathrm{C}$. Growth from such slants was resuspended in $0.9 \% \mathrm{NaCl}$ containing $1 \%(\mathrm{w} / \mathrm{v})$ Tween 80 and used for inoculation of experimental media. The organism was grown under optimal culture conditions on a synthetic medium containing, $\mathrm{g}^{-1}$ : $\mathrm{NaNO}_{3}, 3.0 ; \mathrm{KCl}, 0.5 ; \mathrm{KH}_{2} \mathrm{PO}_{4}, 1.0 ; \mathrm{FeSO}_{4} .7 \mathrm{H}_{2} \mathrm{O}, 0.01$; $\mathrm{MgSO}_{4} \cdot 7 \mathrm{H}_{2} \mathrm{O}, 0.5$; crystalline cellulose, $10 \cdot 0$. The $\mathrm{pH}$ of the medium was adjusted to 5.5 before sterilization (Roy et al., 1988, 1989). Erlenmeyer flasks $(250 \mathrm{ml})$ containing $100 \mathrm{ml}$ of the above medium were inoculated with $1.0 \mathrm{ml}$ of spore suspension $\left(10^{6}\right.$ spores $\left.\mathrm{ml}^{-1}\right)$ and incubated at $50^{\circ} \mathrm{C}$ on a rotary shaker ( 160 r.p.m., 4 cm eccentric throw) for $11 \mathrm{~d}$. After growth, the mycelia were harvested by centrifugation $\left(6000 \mathrm{~g}, 30 \mathrm{~min}, 4^{\circ} \mathrm{C}\right)$ and the supernatants were used as the source of enzyme.

Enzyme assay. Endoglucanase (CMCase) activity was assayed according to Stewart \& Leatherwood (1976). Appropriately diluted enzyme solution and $25 \mathrm{mg} \mathrm{CMC}$ in a final volume of $2 \mathrm{ml}$, adjusted with $50 \mathrm{mM}$-sodium acetate buffer, $\mathrm{pH} 4.8$, were incubated at $65^{\circ} \mathrm{C}$ for $30 \mathrm{~min}$. The reaction was stopped by addition of $0.5 \mathrm{ml} \mathrm{3,5-}$ dinitrosalicylic acid reagent (Miller, 1959), and $A_{540}$ was measured in a Shimadzu UV 240 spectrophotometer. The enzyme activities were obtained from a calibration curve prepared following the same procedure using D-glucose as standard.

One unit (U) of enzyme activity was defined as the amount of enzyme that catalysed the liberation of reducing sugar equivalent to $1.0 \mu \mathrm{mol} \mathrm{D}$-glucose $\mathrm{min}^{-1}$ under the assay conditions. Specific activity was expressed as units (mg protein) $)^{-1}$.

Protein concentrations were determined by the Lowry method, except for the enzyme pools obtained during purification, when $A_{280}$ was used. BSA was used as the standard for both methods.

Purification procedure. All procedures were done at $0-4^{\circ} \mathrm{C}$ unless otherwise indicated. Extracellular endoglucanase was purified from freeze-dried supernatant of broth cultures of $M$. thermophila D-14, which had been stored at $-20^{\circ} \mathrm{C}$.

(a) Ammonium sulphate precipitation. Finely powdered ammonium sulphate was added to the culture supernatant. The endoglucanase activity was associated with the fraction precipitated at $50-80 \%$ saturation. Precipitated proteins were pelleted by centrifugation $(12000 \mathrm{~g})$, dissolved in $50 \mathrm{~mm}$-Tris/ $\mathrm{HCl}$ buffer $\mathrm{pH} \mathrm{7.4}$, and dialysed against the same buffer.

(b) DEAE-Sephadex A-50 chromatography. The dialysed material was applied to a DEAE-Sephadex A-50 column $(2.2 \times 42 \mathrm{~cm})$ equilibrated with $50 \mathrm{~mm}$-Tris/ $\mathrm{HCl}$ buffer $\mathrm{pH} 7 \cdot 4$. The column was washed with 2 bed volumes of buffer and the retained proteins were eluted with a linear $\mathrm{KCl}$ gradient $(500 \mathrm{ml} ; 0-500 \mathrm{mM})$ in the same buffer at a flow rate of $20 \mathrm{ml} \mathrm{h}^{-1}$. The endoglucanase activity in each $5 \mathrm{ml}$ fraction was determined. The active fractions were pooled, concentrated and dialysed extensively against the same buffer.

(c) Rechromatography on DEAE-Sephadex A-50. Dialysed material from the first ion-exchange chromatography step was rechromatographed on a column $(2.2 \times 36 \mathrm{~cm})$ of the same matrix, equilibrated with $50 \mathrm{mM}$-Tris/HCl buffer $\mathrm{pH} 7 \cdot 4$. The column was eluted with a linear $\mathrm{KCl}$ gradient $(500 \mathrm{ml} ; 0-400 \mathrm{mM})$ in the same buffer at a flow rate of $16 \mathrm{ml} \mathrm{h}^{-1}$ and fractions of $4 \mathrm{ml}$ were collected. The active fractions were pooled, concentrated, dialysed extensively against the same buffer and stored at $-20^{\circ} \mathrm{C}$.

Electrophoresis. Non-denaturing PAGE and SDS-PAGE were used to ascertain the degree of protein purity and for estimation of subunit $\boldsymbol{M}_{\mathrm{r}}$. Analytical non-denaturing PAGE was done in tubes in $7.5 \%(\mathrm{w} / \mathrm{v})$ polyacrylamide with Tris/glycine buffer $\mathrm{pH} 8.3$, by the method of Davis (1964). SDS-PAGE was done on slabs $(15 \times 10 \times 0.2 \mathrm{~cm})$ composed of $4 \%(\mathrm{w} / \mathrm{v})$ stacking gels (pH 6.8) and $10 \%(\mathrm{w} / \mathrm{v})$ resolving gels (pH 8.8) containing $0.1 \%$ (w/v) SDS by the method of Laemmli (1970). In both cases gels were stained for protein with Coomassie brilliant blue $\mathbf{R}$ and destained by repeated washing in a solution containing $7 \%(\mathrm{v} / \mathrm{v})$ acetic acid and $5 \%(\mathrm{v} / \mathrm{v})$ methanol. To determine the subunit $M_{\mathrm{r}}$ of the enzyme by SDS-PAGE, gels were run as above in the presence of the following marker proteins: $\beta$-galactosidase $\left(M_{\mathrm{r}}\right.$ $116000)$, BSA (66000), ovalbumin (45000), trypsinogen (24000) and $\beta$ lactoglobulin (18400). Staining with periodic acid/Schiff reagent was used for the detection of glycoproteins according to the Pharmacia manual PAGE Laboratory Techniques (1980).

Gel-filtration chromatography. The native $M_{\mathrm{r}}$ of the purified enzyme was estimated by gel-filtration chromatography through a column $(1.6 \times 75 \mathrm{~cm})$ of Sephadex G-200 (superfine) by the method of Andrews (1964) with $50 \mathrm{~mm}-\mathrm{Tris} / \mathrm{HCl}$ buffer $\mathrm{pH} 7 \cdot 4$, containing $100 \mathrm{~mm}-\mathrm{KCl}$. The column was calibrated with Blue Dextran and standard $M_{\mathrm{r}}$ marker proteins (catalase, $M_{\mathrm{r}} 232000$; aldolase, 158000 ; BSA, 132000). The elution volume $\left(V_{\mathrm{e}}\right)$ was taken to be the sum of fractions up to and including the peak fraction of the respective protein. The void volume $\left(V_{0}\right)$ was assumed to be the elution volume of Blue Dextran. A plot of $V_{\mathrm{e}} / V_{0}$ against $\log M_{\mathrm{r}}$ was used to determine the native $M_{\mathrm{r}}$ of the endoglucanase.

\section{Results}

A typical purification is summarized in Table 1. Purification of one major endoglucanase from the culture supernatant was done as described in Methods. Ammonium sulphate precipitation ( $50-80 \%$ saturation) of the

Table 1. Purification of endoglucanase from culture filtrate of $M$. thermophila $D-14$

\begin{tabular}{|c|c|c|c|c|c|}
\hline $\begin{array}{l}\text { Purification } \\
\text { step }\end{array}$ & $\begin{array}{l}\text { Total protein } \\
(\mathrm{mg})\end{array}$ & $\begin{array}{c}\text { Total activity } \\
\text { (U) }\end{array}$ & $\begin{array}{l}\text { Specific activity } \\
{\left[\mathrm{U}(\mathrm{mg} \text { protein })^{-1}\right]}\end{array}$ & $\begin{array}{c}\text { Yield } \\
(\%)\end{array}$ & $\begin{array}{l}\text { Purification } \\
\quad \text { (-fold) }\end{array}$ \\
\hline Culture filtrate & $283 \cdot 60$ & $460 \cdot 0$ & 1.62 & $100 \cdot 0$ & 1.0 \\
\hline $\begin{array}{l}\text { Ammonium sulphate } \\
\text { precipitation }(50-80 \% \\
\text { saturation) }\end{array}$ & $122 \cdot 60$ & 392.8 & $3 \cdot 20$ & 85.4 & $2 \cdot 3$ \\
\hline $\begin{array}{l}\text { DEAE-Sephadex A-50 } \\
\text { chromatography (I) }\end{array}$ & $5 \cdot 36$ & 80.9 & $15 \cdot 10$ & 17.6 & $9 \cdot 3$ \\
\hline $\begin{array}{l}\text { DEAE-Sephadex A-50 } \\
\text { chromatography (II) }\end{array}$ & 1.69 & $37 \cdot 7$ & $22 \cdot 32$ & $8 \cdot 2$ & 13.8 \\
\hline
\end{tabular}




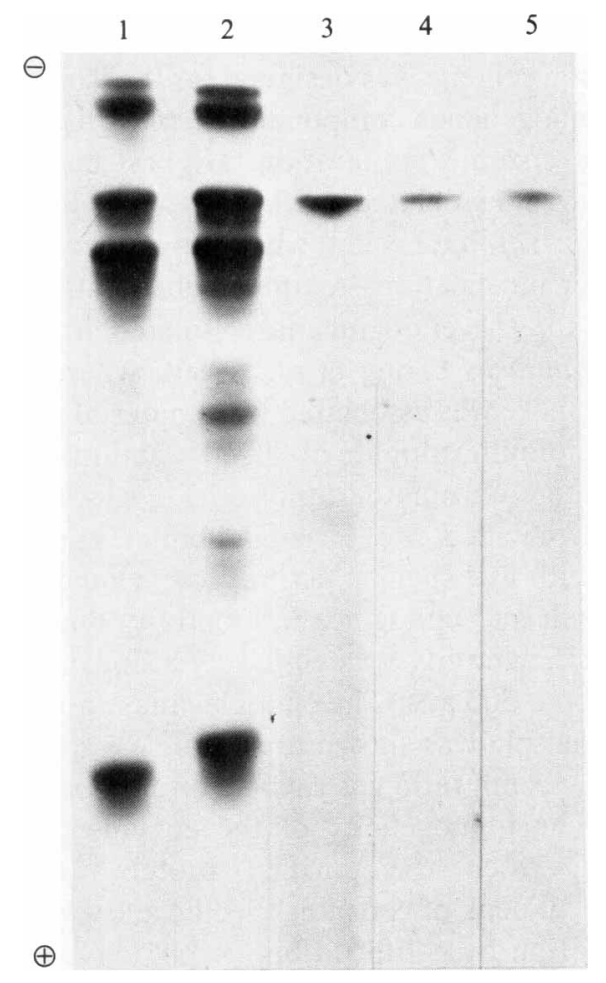

Fig. 1. PAGE of endoglucanase preparations at different steps of purification. Tracks: 1, crude enzyme (130-140 $\mu \mathrm{g}), 2,50-80 \%$ saturation ammonium sulphate fraction $(130-140 \mu \mathrm{g}) ; 3$, pooled active fractions of first DEAE-Sephadex A-50 step $(22 \mu \mathrm{g}) ; 4$ and 5, pooled active fractions from second DEAE-Sephadex A-50 step (15 and $10 \mu \mathrm{g})$.

crude enzyme preparation resulted in recovery of $85 \%$ of the total activity, and $57 \%$ of the total protein was eliminated. The salt-fractionated enzyme preparation was chromatographed on a DEAE-Sephadex A-50 column. The enzyme eluted from the column at approximately $300 \mathrm{mM}-\mathrm{KCl}$. The second DEAE-Sephadex A-50 column step was beneficial in removing trace contaminants. Yield was about $8.2 \%$ of the original total activity and the enzyme was purified approximately 13.8-fold. Homogeneity was determined by non-denaturing PAGE and SDS-PAGE (Fig. 1).

To determine whether the enzyme is a glycoprotein, its sugar content was estimated by the phenol/sulphuric acid method (Dubois et al., 1956). The enzyme protein contained no detectable sugar residues. This was further confirmed by periodic acid/Schiff staining.

The $M_{\mathrm{r}}$ of the purified enzyme was 98000 as determined by gel-filtration chromatography through a calibrated column of Sephadex G-200 (superfine), where the enzyme eluted in a single symmetrical peak. A single band corresponding to an $M_{\mathrm{r}}$ fairly close to this value $(100000)$ was also obtained by SDS-PAGE.

The optimum $\mathrm{pH}$ and temperature for activity of the enzyme under standard assay conditions were 4.8 and
Table 2. Substrate specificity of endoglucanase from $M$. thermophila $D-14$

\begin{tabular}{|c|c|c|c|}
\hline Substrate & Conen & Linkage & $\begin{array}{c}\text { Endoglucanase } \\
\text { activity } \\
\left.[\mathrm{U} \text { (mg protein })^{-1}\right]\end{array}$ \\
\hline $\mathrm{CMC}$ & $12.5 \mathrm{mg} \mathrm{ml}^{-1}$ & $\beta-1,4-$ & $22 \cdot 3$ \\
\hline$\alpha$-Cellulose & $12.5 \mathrm{mg} \mathrm{ml}^{-1}$ & $\beta-1,4$ & $1 \cdot 6$ \\
\hline Solka-Floc & $12.5 \mathrm{mg} \mathrm{ml}^{-1}$ & $\beta-1,4$ & $3 \cdot 1$ \\
\hline Filter paper & $12.5 \mathrm{mg} \mathrm{ml}^{-1}$ & $\beta-1,4$ & 7.8 \\
\hline $\begin{array}{l}\text { Cellulose powder } \\
\text { (microcrystalline) }\end{array}$ & $12.5 \mathrm{mg} \mathrm{ml}^{-1}$ & $\beta-1,4-$ & $2 \cdot 6$ \\
\hline Cotton & $12.5 \mathrm{mg} \mathrm{ml}^{-1}$ & $\beta-1,4-$ & $1 \cdot 1$ \\
\hline Starch & $12.5 \mathrm{mg} \mathrm{ml}^{-1}$ & $\alpha-1,4$ & 0.0 \\
\hline PNPG & $10.0 \mathrm{mM}$ & $\beta-1,4-$ & $0 \cdot 0$ \\
\hline Salicin & $10.0 \mathrm{mM}$ & $\beta-1,4$ & $0 \cdot 0$ \\
\hline
\end{tabular}

Table 3. Effect of cations on the endoglucanase from M. thermophila D-14

\begin{tabular}{|c|c|c|}
\hline Cation & $\begin{array}{l}\text { Concn } \\
\text { (mM) }\end{array}$ & $\begin{array}{c}\text { Relative } \\
\text { activity } \\
(\%)^{*}\end{array}$ \\
\hline Control & - & $100 \cdot 0$ \\
\hline $\mathrm{NH}_{4}^{+}\left[\left(\mathrm{NH}_{4}\right)_{2} \mathrm{SO}_{4}\right]$ & 0.75 & 10.0 \\
\hline $\mathrm{K}^{+}(\mathrm{KCl})$ & $150 \cdot 0$ & $116 \cdot 2$ \\
\hline $\mathrm{Na}^{+}(\mathrm{NaCl})$ & $150 \cdot 0$ & $112 \cdot 1$ \\
\hline $\mathrm{Ag}^{+}\left(\mathrm{AgNO}_{3}\right)$ & 0.075 & 60.2 \\
\hline $\mathrm{Fe}^{2+}\left(\mathrm{FeSO}_{4}\right)$ & 0.75 & $15 \cdot 0$ \\
\hline $\mathrm{Cu}^{2+}\left(\mathrm{CuSO}_{4}\right)$ & 0.75 & $62 \cdot 1$ \\
\hline $\mathrm{Zn}^{2+}\left(\mathrm{ZnSO}_{4}\right)$ & 0.75 & $50 \cdot 0$ \\
\hline $\mathrm{Mg}^{2+}\left(\mathrm{MgSO}_{4}\right)$ & 0.75 & $63 \cdot 3$ \\
\hline $\mathrm{Mn}^{2+}\left(\mathrm{MnSO}_{4}\right)$ & 0.75 & $52 \cdot 1$ \\
\hline $\mathrm{Co}^{2+}\left(\mathrm{CoCl}_{2}\right)$ & 0.75 & $86 \cdot 3$ \\
\hline $\mathrm{Ca}^{2+}\left(\mathrm{CaCl}_{2}\right)$ & 7.5 & $110 \cdot 0$ \\
\hline $\mathrm{Hg}^{2+}\left(\mathrm{HgCl}_{2}\right)$ & 0.75 & $38 \cdot 0$ \\
\hline $\mathrm{Ba}^{2+}\left(\mathrm{BaCl}_{2}\right)$ & $7 \cdot 5$ & $100 \cdot 0$ \\
\hline
\end{tabular}

* Enzyme activity in absence of added substance (control) was taken as $100 \%$, and was equivalent to $0.7 \mathrm{U} \mathrm{ml}^{-1}$.

$65^{\circ} \mathrm{C}$ respectively. The purified endoglucanase was quite stable for $60 \mathrm{~min}$ at temperatures up to $70^{\circ} \mathrm{C}$ but it was denatured above this temperature. At $4{ }^{\circ} \mathrm{C}$ the enzyme was stable over a very broad $\mathrm{pH}$ range $(3 \cdot 5-7 \cdot 0)$, but at room temperature $\left(28^{\circ} \mathrm{C}\right)$ it was stable only in a narrow acidic $\mathrm{pH}$ range $(4 \cdot 5-5 \cdot 5)$.

Purified endoglucanase $\left(180 \mu \mathrm{g} \mathrm{ml}^{-1}\right)$ in $50 \mathrm{~mm}$ sodium acetate buffer pH 4.8 was stable for at least 6 months when stored at $-20^{\circ} \mathrm{C}$. At a concentration of $25 \mu \mathrm{g} \mathrm{ml}^{-1}$ it could be kept at $4^{\circ} \mathrm{C}$ for several days without any apparent loss of activity, but at room temperature $\left(28^{\circ} \mathrm{C}\right)$ the half-life of the enzyme was about $7 \mathrm{~d}$.

Kinetic studies of the purified endoglucanase showed that the $K_{\mathrm{m}}$ for CMC was $3 \mathrm{mg} \mathrm{ml}^{-1}$, as determined from a Lineweaver-Burk plot. 
Table 4. Effect of various reagents on the activity of endoglucanase from $M$. thermophila $D-14$

\begin{tabular}{|c|c|c|}
\hline Compound & Conen & $\begin{array}{c}\text { Relative } \\
\text { activity } \\
(\%)^{*}\end{array}$ \\
\hline Control & - & $100 \cdot 0$ \\
\hline EDTA & $7.5 \mathrm{~mm}$ & $24 \cdot 0$ \\
\hline Sucrose & $2.0 \%(\mathrm{w} / \mathrm{v})$ & $110 \cdot 2$ \\
\hline Glycerol & $7.5 \%(w / v)$ & $118 \cdot 6$ \\
\hline Methanol & $22.5 \%(\mathrm{v} / \mathrm{v})$ & $118 \cdot 2$ \\
\hline Ethanol & $22.5 \%(\mathrm{v} / \mathrm{v})$ & $120 \cdot 0$ \\
\hline Propan-2-ol & $22.5 \%(\mathrm{v} / \mathrm{v})$ & $147 \cdot 1$ \\
\hline 2-Mercaptoethanol & $.4 .0 \mathrm{mM}$ & $174 \cdot 3$ \\
\hline DTT & $5.0 \mathrm{mM}$ & $128 \cdot 0$ \\
\hline Glutathione (reduced) & $5.0 \mathrm{~mm}$ & $160 \cdot 0$ \\
\hline Cysteine & $7.5 \mathrm{mM}$ & $109 \cdot 4$ \\
\hline Glycine & $7.5 \mathrm{~mm}$ & $93 \cdot 1$ \\
\hline Valine & $7.5 \mathrm{mM}$ & $92 \cdot 5$ \\
\hline Iodoacetamide & $7.5 \mathrm{mM}$ & $60 \cdot 8$ \\
\hline PCMB & $0.1 \mathrm{~mm}$ & $56 \cdot 3$ \\
\hline Glucose 1-phosphate & $2.0 \%(\mathrm{w} / \mathrm{v})$ & $100 \cdot 0$ \\
\hline ATP & $3.0 \mathrm{~mm}$ & $199 \cdot 2$ \\
\hline Urea & $2.6 \mathrm{mM}$ & $58 \cdot 4$ \\
\hline SDS & $0.075 \%(w / v)$ & $3 \cdot 2$ \\
\hline Tween 80 & $0.075 \%(w / v)$ & $100 \cdot 0$ \\
\hline Triton $\mathrm{X}-100$ & $0.075 \%(w / v)$ & $95 \cdot 7$ \\
\hline BSA & $7.5 \mathrm{mg} \mathrm{ml}^{-1}$ & $109 \cdot 2$ \\
\hline
\end{tabular}

* See Table 3.

The ability of the purified enzyme to use a number of substrates was tested (Table 2). The enzyme displayed highest activity towards CMC and significantly lower activity towards filter paper and Solka-Floc, followed by $\alpha$-cellulose, cellulose powder and cotton. The purified enzyme did not exhibit detectable $\beta$-glucosidase or amylolytic activity.

Significant inactivation of the enzyme was observed with $\mathrm{NH}_{4}^{+}, \mathrm{Fe}^{2+}, \mathrm{Cu}^{2+}$ and $\mathrm{Hg}^{2+} . \mathrm{K}^{+}, \mathrm{Na}^{+}$and $\mathrm{Ca}^{2+}$ enhanced the enzyme activity (Table 3 ).

Among the various reagents tested (Table 4), thiols and alcohols stimulated enzyme activity but the thiolgroup-binding agents (iodoacetamide, PCMB), urea, SDS and EDTA were inhibitory.

\section{Discussion}

The cellulases of true cellulolytic organisms are now well-established as multicomponent enzyme systems. The components include 1,4- $\beta$-D-glucan glucanohydrolase, 1,4- $\beta$-D-glucan cellobiohydrolase and $\beta$-glucosidase (Wood \& McCrea, 1978; Ramasamy \& Verachtert, 1980; Funaguma \& Hara, 1988).

It is generally agreed that it is difficult to obtain a single cellulase component in a homogeneous state $(\mathrm{Ng}$ \& Zeikus, 1981). $M$. thermophila D-14, like other cellulolytic organisms, produces a mixture of hydrolytic enzymes in the culture filtrate. In the present investigation the purification scheme was designed for the isolation of one major homogeneous component of endoglucanase from the crude enzyme preparation. Highest endoglucanase activity was associated with the $50-80 \%$ saturation ammonium sulphate pellet, which was collected and used for further purification. A similar observation has been reported for the endoglucanase isolated from Thermoascus aurantiacus (Tong et al., 1980), where the major endoglucanase was associated with material precipitated with ammonium sulphate at $30-40 \%$ saturation. During ion-exchange chromatography on DEAE-Sephadex A50 at $\mathrm{pH} 7.4$ with $50 \mathrm{mM}$-Tris/HCl buffer, endoglucanase activity with low specific activity was eluted during the buffer wash and endoglucanase activity with relatively high specific activity was eluted by a linear gradient of $\mathrm{KCl}$ at about $300 \mathrm{mM}$. The endoglucanase activity of the purified sample was shown to comprise a single protein species by its migration as a single protein band on SDSPAGE. The homogeneity of the enzyme protein was confirmed when the purified protein eluted as a symmetrical peak of constant specific activity during $M_{\mathrm{r}}$ determination by gel filtration.

The endoglucanase of $M$. thermophila D-14 has a higher $M_{\mathrm{r}}$ than other purified endoglucanases. Generally, endoglucanases are low- $M_{\mathrm{r}}$ proteins, e.g. Trichoderma viride, $M_{\mathrm{r}} 37000,52000$ and 49000 (Shoemaker \& Brown, 1978); Sporotrichum pulverulentum, $M_{\mathrm{r}} 32000,36700$, 28300, 37500 and 37000 (Eriksson \& Pettersson, 1975); and Bacillus subtilis, $M_{\mathrm{r}} 23000$ (Au \& Chan, 1987). However, a high- $M_{\mathrm{r}}$ endoglucanase was reported in Clostridium thermocellum $\left(M_{\mathrm{r}}\right.$ 94000) $(\mathrm{Ng}$ \& Zeikus, $1981)$ and in Thermomonospora curvata $\left(M_{\mathrm{r}} 114000\right)$ (Lupo \& Stutzenberger, 1988). The results from gel filtration and SDS-PAGE both indicated that the endoglucanase from $M$. thermophila D-14 was likely to be a single peptide protein. This is in agreement with the fact that extracellular enzymes are generally composed of one peptide (Pugsley \& Schwartz, 1985).

The purified endoglucanase from $M$. thermophila D-14 is not a glycoprotein, as also shown by Eriksson \& Pettersson (1975) for the enzyme from Sporotrichum.

Cellulolytic enzymes are generally thermostable, with high temperature optima (Tong et al., 1980; Au \& Chan, 1987). The endoglucanase from $M$. thermophila $\mathrm{D}-14$ has a temperature optimum of $65^{\circ} \mathrm{C}$ for activity and is stable up to $70^{\circ} \mathrm{C}$ for $60 \mathrm{~min}$. The $\mathrm{pH}$ optimum of cellulolytic enzymes is usually between $\mathrm{pH} 4 \cdot 0$ and $\mathrm{pH} 6.0$ (Tong $e t$ al., 1980). The $\mathrm{pH}$ optimum of the endoglucanase from M. thermophila D-14 was 4.8 in $50 \mathrm{~mm}$-sodium acetate buffer and the enzyme was stable over a broad range of $\mathrm{pH}(4 \cdot 0-7 \cdot 0)$.

The $K_{\mathrm{m}}\left(3 \mathrm{mg} \mathrm{ml}^{-1}\right)$ for CMC of purified endoglucanase from $M$. thermophila D-14 is similar to that of the 
enzyme from Bacillus subtilis (4 $\mathrm{mg}^{-1}$ ) (Au \& Chan, 1987) and higher than that of the enzyme from Thermoascus aurantiacus $\left(1.9 \mathrm{mg} \mathrm{ml}^{-1}\right)$ (Tong et al., 1980).

The effects of ions on enzyme activity (Table 3 ) may be due to changes in electrostatic bonding, which would change the tertiary structure of the enzyme. Enhancement of enzyme activity in the presence of thiol compounds, e.g. cysteine, glutathione (reduced) and DTT, and inhibition of activity by thiol-group-blocking agents such as PCMB and iodoacetamide, suggests the possible involvement of thiol groups in the active site of the enzyme. The inhibition of activity may be explained by destabilization caused by alteration in protein structure brought about by disruption of disulphide bridges. Similar observations were reported for the enzyme from Acetivibrio cellulolyticus (Mackenzie \& Bilous, 1982), Humicola lanuginosa (Olutiola, 1982) and Bacillus subtilis (Au \& Chan, 1987). Inhibition of enzyme activity in the presence of EDTA may be due to the chelation of certain metal ions required for activation and/or stabilization of the enzyme.

Lastly, it should be emphasized that the work described so far represents the purification and properties of a major endoglucanase component, and that this does not represent the total endoglucanase activity of $M$. thermophila D-14.

The authors thank the CSIR, New Delhi, for financial assistance. Thanks are also due to Professor B. B. Biswas, Director, Bose Institute, Calcutta for providing research facilities and encouragement.

\section{References}

ANDREwS, P. (1964). Estimation of molecular weight of protein by Sephadex gel filtration. Biochemical Journal 91, 222-233.

AU, K. S. \& Chan, H. Y. (1987). Purification and properties of the endo-1,4- $\beta$-glucanase from Bacillus subtilis. Journal of General Microbiology 133, 2155-2162.

DAVIS, B. J. (1964). Disc electrophoresis. II. Method and application to serum proteins. Annals of the New York Academy of Sciences 121, 404-427.

Dubois, M., Gilles, K. A., Hamilton, J. K., Rebers, P. A. \& Smith, F. (1956). Colorimetric method for determination of sugars and related substances. Analytical Chemistry 28, 350-356.

ERIKSEN, J. \& GoKSOYR, J. (1976). The effect of temperature on growth and cellulase $(\beta$-1,4-endoglucanase) production in the compost fungus Chaetomium thermophile var. dissitum. Archives of Microbiology 110, 233-238.

Eriksson, K. E. \& Petrersson, B. (1975). Extracellular enzyme system utilized by the fungus Sporotrichum pulverulentum (Chrysosporium lignorum) for the breakdown of cellulose. European Journal of Biochemistry 51, 193-206.
Funaguma, T. \& HaRa, A. (1988). Purification and properties of two $\beta$ glucosidases from Penicillium herguei Banier and Sartory. Agricultural and Biological Chemistry 52, 749-755.

LAEMMLI, U. K. (1970). Cleavage of structural proteins during assembly of the head of the bacteriophage T4. Nature, London 227, 680-685.

LANGSFORD, M. L., GilKes, N. R., WaKarchuK, W. W., KilburN, D. G., Miller, R. C., JR \& WARREN, R. A. J. (1984). The cellulase system of Cellulomonas fimi. Journal of General Microbiology 130 , 1367-1376.

LUPO, D. \& StUTZENBERger, F. (1988). Changes in endoglucanase patterns during growth of Thermomonospora curvata on cellulose. Applied and Environmental Microbiology 54, 588-589.

MACKenZIE, C. R. \& Bilous, D. (1982). Location and kinetic properties of the cellulase system of Acetivibrio cellulolyticus. Canadian Journal of Microbiology 28, 1158-1164.

MANDELS, M. (1982). Cellulases. In Annual Reports on Fermentation Processes, vol. 5, pp. 35-78. Edited by G. T. Tsao. New York: Academic Press.

MILLER, G. L. (1959). Use of dinitrosalicylic reagent for determination of reducing sugar. Analytical Chemistry 31, 426-428.

Moreira, A. R., Phillips, J. A. \& Humphrey, A. E. (1981). Production of cellulases by Thermomonospora sp. Biotechnology and Bioengineering 23, 1339-1347.

NG, T. K. \& ZeIKUS, J. G. (1981). Purification and characterization of an endoglucanase from Clostridium thermocellum. Biochemical Journal 199, 341-350.

Olutiola, P. O. (1982). Characterization of cellulase from Humicola lanuginosa. Experientia 38, 1332-1333.

Pugsley, A. P. \& SChWARTZ, M. (1985). Export and secretion of proteins by bacteria. FEMS Microbiology Reviews 32, 3-38.

RAMASAMY, K. \& VerachterT, H. (1980). Location of cellulase components in Pseudomonas sp. isolated from activated sludge. Journal of General Microbiology 117, 181-191.

Romanelit, R. A., Houston, C. W. \& BarNETT, S. M. (1975). Studies on thermophilic fungi. Applied Microbiology 30, 276-281.

ROSENBERG, S. L. (1975). Temperature and $\mathrm{pH}$ optima for 21 species of thermophilic and thermotolerant fungi. Canadian Journal of Microbiology 21, 1535-1540.

Roy, S. K., RaHa, S. K., Dey, S. K. \& Chakrabarty, S. L. (1988). Induction and catabolite repression of $\beta$-glucosidase synthesis in Myceliophthora thermophila D-14 (ATCC 48104). Applied and Environmental Microbiology 54, 2152-2153.

Roy, S. K., Raha, S. K., Dey, S. K. \& Chakrabarty, S. L. (1989). Immobilization of $\beta$-glucosidase from Myceliophthora thermophila D-14. Enzyme and Microbial Technology 11, 431-435.

Roy, S. K., Raha, S. K., Dey, S. K. \& Chakrabarty, S. L. (1990). Effect of temperature on the production and location of cellulase complex in Myceliophthora thermophila D-14. Enzyme and Microbial Technology (in the Press).

Sen, S., Abraham, T. K. \& Chakrabarty, S. L. (1981). Cellulolytic activity of Myceliophthora thermophila D-14. Current Science 50, 598600.

Sen, S., Abraham, T. K. \& Chakrabarty, S. L. (1982). Characteristics of the cellulase produced by Myceliophthora thermophila D-14. Canadian Journal of Microbiology 28, 271-277.

Sen, S., Abraham, T. K. \& Chakrabarty, S. L. (1983). Induction of cellulase in Myceliophthora thermophila D-14. Canadian Journal of Microbiology 29, 1258-1260.

SHOEMAKER, S. P. \& BROWN, R. D. JR (1978). Characterization of endo1,4- $\beta$-D-glucanases purified from Trichoderma viride. Biochimica et Biophysica Acta 523, 147-161.

STEWART, B. J. \& LeATHER wOOD, J. M. (1976). Derepressed synthesis of cellulase by Cellulomonas. Journal of Bacteriology 128, 609-615.

TONG, C. C., Cole, A. L. \& SHEPHERd, M. F. (1980). Purification and properties of the cellulases from the thermophilic fungus Thermoascus aurantiacus. Biochemical Journal 191, 83-94.

Wood, T. M. \& MCCraE, S. L. (1978). The cellulase of Trichoderma koningii. Biochemical Journal 171, 61-72. 